\title{
Autosomal Recessive Infantile Hypercalcemia
}

National Cancer Institute

\section{Source}

National Cancer Institute. Autosomal Recessive Infantile Hypercalcemia. NCI Thesaurus. Code C129734.

A condition caused by autosomal recessive loss-of-function mutation(s) in the CYP24A1 or SLC34A1 gene, encoding mitochondrial 1,25-dihydroxyvitamin D(3) 24-hydroxylase, and sodium-dependent phosphate transport protein $2 \mathrm{~A}$, respectively. This condition is characterized by vomiting, polyuria, dehydration, and failure to thrive, accompanied by hypercalcemia, suppressed parathyroid hormone, and nephrocalcinosis. 